\title{
Pengaruh Pendidikan Kesehatan terhadap Keaktifan Kader di Desa Taman Kecamatan Grujugan Kabupaten Bondowoso
}

\author{
Yessy Nur Endah Sary ${ }^{1}$, Diah Puspasari ${ }^{2}$ \\ ${ }^{1}$ STIKes Hafshawaty Pesantren Zainul Hasan \\ Email: yessynurendahsari@gmail.com
}

Received 31 August 2018; Accepted 31 August 2018; Published 6 November 2018

\begin{abstract}
ABSTRAK
Keberhasilan posyandu ditentukan kinerja kader posyandu, karena kader adalah penggerak posyandu dan hidup matinya posyandu tergantung aktif tidaknya kader. Minimalnya pelatihan dan pembinaan dalam rangka meningkatkan keterampilan yang memadai bagi kader menyebabkan minimalnya pemahaman terhadap tugas kader, lemahnya informasi serta minimalnya koordinasi antara petugas dengan kader dalam melaksanaan kegiatanan posyandu sehingga mengakibatkan rendahnya tingkat kehadiran anak Bawah Lima Tahun (balita) ke posyandu dan rendahnya cakupan deteksi dini tumbuh kembang balitaTujuan penelitian untuk menganalisis pengaruh pendidikan kesehatan terhadap keaktifan kader di Desa Taman Kecamatan Grujugan Kabupaten Bondowoso. Metode pendekatan yang digunakan adalah pre-eksperimental design dengan jenis one-group pretestposttest design. Populasi dalam penelitian ini adalah seluruh kader posyandu di Desa Taman berjumlah 38 orang. Teknik Sampling yang digunakan adalah sampling jenuh. Sampel penelitian seluruh kader posyandu di Desa Taman berjumlah 38 orang. Teknik pengolahan data yaitu editing, coding, scoring, tabulating. Analisis univariat dengan distribusi frekuensi, sedangkan analisis bivariat dengan menggunakan uji Wilcoxon Match Paired Test. Hasil pengujian dengan Wilcoxon Match Paired Test diketahui bahwa $\rho$ value $(0,014)<$ alpha $(0,05)$ dengan demikian, maka Ha diterima yang artinya ada pengaruh pendidikan kesehatan terhadap keaktifan kader di Desa Taman Kecamatan Grujugan Kabupaten Bondowoso. Disarankan untuk puskesmas dan dinas kesehatan untuk mengadakan pertemuan rutin dengan kader untuk menambah wawasan kader.
\end{abstract}

Kata kunci: Keaktifan kader, pendidikan kesehatan

Copyright $(92018$ STIKes Surya Mitra Husada

All right reserved.

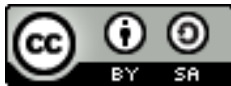

This is an open-acces article distributed under the terms of the Creative Commons AttributionShareAlike 4.0 International License.

\section{PENDAHULUAN}

Posyandu adalah suatu Upaya Kesehatan Bersumber Daya Masyarakat (UKBM) yang dikelola dan diselenggarakan dari, oleh, untuk dan dengan masyarakat dalam penyelenggaraan pembangunan kesehatan yang bertujuan untuk memberdayakan masyarakat dan memperoleh pelayanan kesehatan dasar sehingga mempercepat penurunan angka kematian ibu dan bayi (Kemenkes RI, 2012). Posyandu dikelola puskesmas, kader dan masyarakat secara aktif untuk mendekatkan kebutuhan layanan. Peran kader sangat penting karena bertanggung jawab penuh dalam 
pelaksanaan program posyandu. Cakupan kunjungan balita di posyandu merupakan indikator baik/buruknya pelaksanaan posyandu.

Pada tahun 2017, jumlah Posyandu di Indonesia sebanyak 266.827 yang tersebar di seluruh Indonesia dan terdapat sekitar 3 sampai 5 orang kader per Posyandu dan berarti ada lebih dari 1 juta kader Posyandu (Kemenkes RI, 2011). Kabupaten Bondowoso jumlah Posyandu Aktif (Purnama Mandiri) terus mengalami kenaikan dari tahun 2015-2017. Pada Tahun 2017 jumlah Posyandu yang ada di Kabupaten Bondowoso sebanyak 1.055 Posyandu. Dari jumlah tersebut, Posyandu aktif (PURI) sebanyak 460 Posyandu (43,60\%). Cakupan pelayanan kesehatan anak balita pada tahun 2017 adalah 38.280 balita $(88,1 \%)$ dari jumlah balita 43.444 balita). Jumlah posyandu di kecamatan Grujugan tahun 2017 adalah 50 posyandu dengan jumlah kader aktif sebanyak 232 orang dari 250 kader yang ada atau sekitar 7,2 \% kader drop out diwilayah kerja Puskesmas Grujugan dengan total desa sebanyak 11. Jumlah drop out kader terbanyak adalah di Desa Taman (Dinkes Bondowoso, 2017).

Keberhasilan posyandu ditentukan kinerja kader posyandu, karena kader adalah penggerak posyandu dan hidup matinya posyandu tergantung aktif tidaknya kader. Minimalnya pelatihan dan pembinaan dalam rangka meningkatkan keterampilan yang memadai bagi kader menyebabkan minimalnya pemahaman terhadap tugas kader, lemahnya informasi serta minimalnya koordinasi antara petugas dengan kader dalam melaksanaan kegiatanan posyandu sehingga mengakibatkan rendahnya tingkat kehadiran anak Bawah Lima Tahun (balita) ke posyandu dan rendahnya cakupan deteksi dini tumbuh kembang balita (Harisman, 2012).

Permasalahan yang berkaitan dengan para kader adalah tingginya drop out kader. Kehadiran seorang kader di posyandu sangat dipengaruhi oleh umur, pengetahuan, pekerjaan, status perkawinan serta pendidikan (Nilawati, 2008). Permasalahan yaitu kurangnya pengetahuan mengenai tugas dan fungsinya sehingga berdampak pada keaktifan. Faktor eksternal yang berhubungan yaitu perhatian dan bimbingan petugas kesehatan serta penghargaan dari tokoh masayarakat dan masyarakat sekitar.

Berdasarkan data di Desa Taman angka drop out Kader posyandu adalah 15.6\% dan cakupan kunjungan ke Posyandu di Desa Taman sebesar 70\% sedangkan target yang harus dicapai adalah $80 \%$. Berdasarkan hasil observasi awal yang dilakukan dengan metode wawancara dengan beberapa kader pada tanggal 13 Nopember 2017 menjelaskan bahwa kader selama ini hanya mengikuti tugas yang dilakukan oleh kader lainnya, artinya tidak ada pendidikan khusus kader berkaitan dengan tugasnya. Hal ini mengakibatkan kader tidak mengetahui secara pasti mengenai perannya dalam posyandu ataupun dalam masyarakat. Selain itu, pola perekrutan kader berdasarkan pada kemauan kader tidak berdasarkan pada kemampuan. Hal ini diduga menjadi pemicu keaktifan kader serta keberhasilan kegiatan posyandu

Keaktifan kader merupakan bentuk dari perilaku yang sangat dipengaruhi oleh pendidikan kesehatan. Pendidikan kesehatan menunjang program-program kesehatan yang lain serta membawa manfaat bagi masyarakat yang mudah dilihat atau diukur, karena merupakan behavioral investmen jangka panjang. Pendidikan mengubah pemahaman kesehtan seseorang menjadi dasar terbentuk perilaku sebagai hasil jangka menengah .

Upaya yang dilakukan pemerintah khususnya Dinas Kesehatan Kabupaten Bondowoso melalui Puskesmas yang ada untuk menjaga dan meningkatkan keaktifan kader adalah dengan melakukan refreshing kader. Kegiatan ini dilakukan selama 1 tahun sekali dengan mengajak perwakilan kader dari masing-masing posyandu. Kegiatan ini berisi penyegaran kembali mengenai peran serta kader dalam peosyandu. Kegaiatan ini sangat positif namun kurang efektif, karena yang tidak semua kader terlibat. Harapan dari kegiatan ini adalah meningkatnya partisipasi kader terutama dalam kegiatan posyandu.

\section{BAHAN DAN METODE}

Metode pendekatan yang digunakan adalah pre-eksperimental design dengan jenis one-group pretest-posttest design. Populasi dalam penelitian ini adalah selurah kader posyandu di Desa Taman berjumlah 38 orang. Teknik Sampling yang digunakan adalah sampel jenuh. Sampling Jenuh. Sampel penelitian seluruh kader posyandu di Desa Taman berjumlah 38 orang. Teknik pengolahan data yaitu editing, coding, scoring, tabulating. Analisis univariat dengan distribusi frekuensi, sedangkan analisis bivariat dengan menggunakan uji Wilcoxon Match Paired Test. 
HASIL

Data Khusus

Distribusi Frekuensi Responden Berdasarkan Keaktifan kader sebelum pendidikan kesehatan di Desa Taman Kecamatan Grujugan Kabupaten Bondowoso tahun 2018

Tabel 5Distribusi Frekuensi Responden Berdasarkan Keaktifan kader sebelum pendidikan kesehatan di Desa Taman Kecamatan Grujugan Kabupaten Bondowoso tahun 2018

\begin{tabular}{cccc}
\hline No & Keaktifan Kader & Frekuensi & Persentase (\%) \\
\hline 1 & Aktif & 25 & 65.8 \\
\hline 2 & Tidak aktif & 13 & 34.2 \\
\hline & Jumlah & 38 & 100 \\
\hline
\end{tabular}

Berdasarkan tabel 5 diperoleh bahwa sebagian besar keaktifan kader sebelum pendidikan kesehatan berada pada kategori aktif sebanyak 25 orang $(65,8 \%)$.

Distribusi Frekuensi Keaktifan kader sesudah pendidikan kesehatan di Desa Taman Kecamatan Grujugan Kabupaten Bondowoso tahun 2018

Tabel 6 Distribusi Frekuensi Keaktifan kader sesudah pendidikan kesehatan di Desa Taman Kecamatan Grujugan Kabupaten Bondowoso tahun 2018

\begin{tabular}{cccc}
\hline No & Keaktifan kader sesudah pendidikan kesehatan & Frekuensi & Persentase (\%) \\
\hline 1 & Aktif & 31 & 81.6 \\
\hline 2 & Tidak aktif & 7 & 18.4 \\
\hline & Jumlah & 38 & 100 \\
\hline
\end{tabular}

Berdasarkan tabel 6 diperoleh bahwa sebagian besar keaktifan kader sesudah pendidikan kesehatan berada pada kategori aktif sebanyak 31 orang $(81,6 \%)$.

Tabulasi Silang Keaktifan Kader sebelum dan sesudah pendidikan kesehatan di Desa Taman Kecamatan Grujugan Kabupaten Bondowoso tahun 2018

Tabel 7 Tabulasi Silang Keaktifan Kader sebelum dan sesudah pendidikan kesehatan di Desa Taman Kecamatan Grujugan Kabupaten Bondowoso tahun 2018

\begin{tabular}{|c|c|c|c|c|c|c|c|}
\hline \multirow{3}{*}{ No } & \multirow{3}{*}{ Pendidikan kesehatan } & \multicolumn{4}{|c|}{ Keaktifan kader sesudah pendidikan kesehatan } & \multirow{2}{*}{\multicolumn{2}{|c|}{ Peningkatan }} \\
\hline & & \multicolumn{2}{|c|}{ Aktif } & \multicolumn{2}{|c|}{ Tidak aktif } & & \\
\hline & & $\mathrm{f}$ & $\%$ & $f$ & $\%$ & $\sum$ & $\%$ \\
\hline 1 & Sebelum & 25 & 65.8 & 13 & 34.2 & 12 & 21,05 \\
\hline 2 & Sesudah & 31 & 81.6 & 7 & 18.4 & 24 & 57,89 \\
\hline & Peningkatan & 6 & 39,47 & 6 & 39,47 & 12 & 21,05 \\
\hline
\end{tabular}

Berdasarkan tabel 7 di atas dapat diketahui bahwa Keaktifan kader sesudah pendidikan kesehatan cenderung meningkat sebesar $39,47 \%$. 


\section{Analisis Data}

Hasil pengujian dengan Wilcoxon Match Paired Test diketahui bahwa $\rho$ value $(0,014)<$ alpha $(0,05)$ dengan demikian, maka ha diterima sehingga ada pengaruh pendidikan kesehatan terhadap keaktifan kader di Desa Taman Kecamatan Grujugan Kabupaten Bondowoso.

\section{PEMBAHASAN}

Umur, pendidikan, pekerjaan, lama menjadi kader

\section{Mengidentifikasi keaktifan kader sebelum diberikan pendidikan kesehatan di Desa Taman Kecamatan Grujugan Kabupaten Bondowoso.}

Berdasarkan hasil penelitian pada tabel 5 diperoleh bahwa sebagian besar keaktifan kader sebelum pendidikan kesehatan berada pada kategori aktif sebanyak 25 orang $(65,8 \%)$.

Menurut Anggidin (2011), kader Posyandu merupakan warga yang tinggal di masyarakat yang ditunjuk sukarela dalam melaksanakan kegiatan pelayanan kesehatan sederhana di Posyandu. Kader Posyandu dipilih pengurus Posyandu dari anggota masyarakat yang bersedia dengan sukarela, mampu dan memiliki waktu luang untuk menyelenggarakan kegiatan Posyandu. Keaktifan kader diartikan aktif melaksanakan tugasnya dengan baik sesuai dengan wewenang dan tanggung jawabnya. Akan tetapi jika kader kesehatan tidak mampu melaksanakan tugasnya dengan baik maka mereka tergolong tidak aktif (Rochmawati, 2010).

Kader yang lebih lama bekerja akan lebih paham dan mengerti akan kegiatan yang harus dilaksanakan di posyandu seperti pendaftaran, penimbangan, pencatatan, dan penyuluhan. Kader diharapkan aktif dan mampu menjadi pendorong, motivator dan penyuluh masyarakat serta menjembatani petugas kesehatan dengan masyarakat serta membantu masyarakat mengidentifikasi dan memenuhi kebutuhan kesehatan. Keaktifan kader sangat menentukan keberhasilan posyandu. Kader di Desa Taman secara jumlah sangat memuhi syarat. Kader lebih berperan terhadap kegiatan yang ada di posyandu semata sementara tugas lain berkaitan dengan mengajak masyarakat, mengidentifikasi dan memenuhi kebutuhan masyarakat akan keehatan kurang berjalan baik. Hal ini disebabkan karena minimnya pengetahuan yang dimiliki kader mengenai tugas-tugasnya.

\section{Mengidentifikasi keaktifan kader sesudah diberikan pendidikan kesehatan di Desa Taman Kecamatan Grujugan Kabupaten Bondowoso.}

Berdasarkan hasil penelitian pada tabel 6 diperoleh bahwa sebagian besar keaktifan kader sesudah pendidikan kesehatan berada pada kategori aktif sebanyak 31 orang $(81,6 \%)$.

Lama kerja berkaitan dengan pengalaman. Pengalaman yang lebih lama mempunyai pengaruh terhadap keaktifan seseorang dalam bekerja terutama kader. Begitu juga dengan tingkat pendidikan kader. Sebagian besar kader hanyalah berpendidikan sekolah dasar. Hal inilah yang membuat para kader hanya mempunyai pengetahuan dan informasi yang minimal mengenai peran dan tugas kader. Maka dari itu, diadakan pendidikan kesehatan secara teratur dan berkala. Menurut Nursalam (2008) pendidikan kesehatan adalah salah satu kegiatan untuk membantu individu, keluarga, atau masyarakat untuk meningkatkan kemampuan atau perilaku guna mencapai kesehatan secara maksimal.

Pendidikan kesehatan terhadap kader posyandu merupakan upaya untuk meningkatkan pengetahuan yang dimiliki berkaitan dengan tugas yang dikerjakan oleh kader sehari-hari (Nursalam, 2008). Dengan pengetahuan baik akan memiliki kecenderungan kader akan semakin aktif dalam menjalankan kewajibannya sebagai kader. Ketidaktahuan kader atau minimalnya informasi selama ini mengenai tugasnya menjadi kendalan keberhasilan posyandu. Oleh karena pemberian pendidikan kesehatan terhadap kader secara baik dan tepat akan mampu meningkatkan perannya dan mendukung terpenuhinya cakupan. 


\section{Menganalisis pengaruh pendidikan kesehatan terhadap keaktifan kader di Desa Taman Kecamatan Grujugan Kabupaten Bondowoso.}

Berdasarkan hasil uji Wilcoxon Match Paired Test diketahui bahwa signifikansi 0,014 < 0,05 dengan demikian, maka ha diterima sehingga ada pengaruh pendidikan kesehatan terhadap keaktifan kader di Desa Taman Kecamatan Grujugan Kabupaten Bondowoso.

Menurut Notoatmodjo, (2010) pendidikan kesehatan sekaligus bertujuan sebagai promosi kesehatan dengan mengupayakan agar perilaku individu, kelompok, atau masyarakat mempunyai pengaruh positif pada peningkatan kesehatan. Kegiatan promosi kesehatan berupaya memberikan informasi atau pesan kesehatan berupa penyuluhan peningkatkan pengetahuan dan sikap tentang kesehatan untuk menjadikan perilaku sehat.

Pendidikan kesehatan terbukti memberikan berdampak pada keaktifan kader. Adanya hubungan pendidikan kesehatan dan pendidikan kader dapat dipahami bahwa dalam pemberian pendidikan kesehatan terdapat beberapa informasi yang disampaikan oleh bidan atau petugas kesehatan baik dari puskesmas ataupun dinas kesehatan. Kader yang awalnya tidak tahu menjadi tahu mengenai tugas-tugasnya. Sementara peran merupakan suatu tindakan atau perilaku didasari oleh pengetahuan atau informasi yang dimiliki. Kader berperan atau berperilaku sesuai dengan apa yang diketahuinya. Sejauh ini peran kader hanya dominan di kegiatan posyandu sementara pada kegaitan kemasyarakat masih kurang bisa disebabkan karena minimnya informasi yang dimilikinya.

\section{KESIMPULAN}

Terdapat pengingkatan keaktifan kader sesudah pendidikan kesehatan yang berarti ada pengaruh pendidikan kesehatan terhadap keaktifan kader di Desa Taman Kecamatan Grujugan Kabupaten Bondowoso.

\section{REFERENSI}

Anggidin, S. (2011). Peran kader posyandu di wilayah binaan NICE. Depertemen Kesehatan Republik Indonesia. Jakarta. Artikel (Online). (http://gizi.depkes.go.id Diakses pada tanggal 12 Desember 2017).

Harisman. (2012). Faktor-faktor Mempengaruhi Keaktifan Kader Posyandu di Desa Mulangmaya Kec.Kotabumi Selatan Kab.Lampung Utara. Universitas Malahayati : Lampung Utara

Menkes RI. 2014. Peraturan Menteri Kesehatan RI Nomor 27 Tahun 2014 tentang Petunjuk Teknis Sistem Indonesian Case Base Groups (CBGs).

Kemenkes RI, (2011). Laporan Akhir Riset Fasilitas Kesehatan tahun 2011. Jakarta: Kemenkes RI.

Kemenkes RI, (2012). Buku Panduan Kader Posyandu Menuju Keluarga Sadar Gizi. Jakarta:Kemenkes RI.

Nilawati, (2008). Pengaruh Karakteristik Kader dan Strategi Revitalisasi Posyandu Terhadap Keaktifan Kader di Kecamatan Samdua Kabupaten Aceh Selatan Tahun 2008 (Tesis). Medan; USU.

Notoatmojo. (2010). Etika \& Hukum Kesehatan. Jakarta: Rineka Cipta.

Nursalam. (2008). Konsep dan penerapan metodologi penelitian keperawatan. Jakarta.

Rochmawati. (2010). Hubungan Antara Keaktifan Kader Kesehatan dengan Pengembangan Program Desa Siaga di Kecamatan Masaran Kabupaten Sragen. Skripsi. Universitas Sebelas Maret. Surakarta. 